University of Nebraska - Lincoln

DigitalCommons@University of Nebraska - Lincoln

Agronomy \& Horticulture -- Faculty Publications

Agronomy and Horticulture Department

February 1989

\title{
Genetic Variability for Seedling Atrazine Tolerance in Indiangrass
}

J. G. Kube

USDA-SCS, Cape May Plant Materials Ctr.

Kenneth P. Vogel

University of Nebraska-Lincoln, kvogel1@unl.edu

Lowell E. Moser

University of Nebraska-Lincoln, Imoser1@unl.edu

Follow this and additional works at: https://digitalcommons.unl.edu/agronomyfacpub

Part of the Plant Sciences Commons

Kube, J. G.; Vogel, Kenneth P.; and Moser, Lowell E., "Genetic Variability for Seedling Atrazine Tolerance in Indiangrass" (1989). Agronomy \& Horticulture -- Faculty Publications. 80.

https://digitalcommons.unl.edu/agronomyfacpub/80

This Article is brought to you for free and open access by the Agronomy and Horticulture Department at DigitalCommons@University of Nebraska - Lincoln. It has been accepted for inclusion in Agronomy \& Horticulture -Faculty Publications by an authorized administrator of DigitalCommons@University of Nebraska - Lincoln. 


\title{
Genetic Variability for Seedling Atrazine Tolerance in Indiangrass
}

\author{
J. G. Kube, K. P. Vogel, ${ }^{*}$ and L. E. Moser
}

\begin{abstract}
Indiangrass [Sorghastrum nutans (L.) Nash] lacks sufficient seedling atrazine [6-chloro- $N$-ethyl- $N$-(1-methylethyl)-1,3,5-triazine-2,4diamine] tolerance to permit the use of atrazine as a pre-emergence herbicide. The principle objective of this study was to estimate the genetic variability for seedling atrazine tolerance in two indiangrass populations, 'Nebraska 54' and 'Holt', using seed harvested from replicated clones. Seedling survival in soil containing $3 \mathbf{m g ~ k g} \mathbf{~ g g}^{-1}$ atrazine was determined in the greenhouse. There was significant genetic variability among half-sib families of both populations for seedling atrazine tolerance. Heritability estimates were greater than 0.50. There was also significant genetic variability among the parent plants of both populations for atrazine tolerance as measured by the change in relative fluorescence (CRF) of leaf disks exposed to atrazine. Atrazine blocks photosynthesis, causing differential fluorescence among plants differing in tolerance, which can be measured with a fluorometer. Correlations of CRF of the parent plants and the seedling atrazine tolerance of their progeny were low $(r<0.3)$ indicating that fluorescence assay would not be asable screening procedure. Improving the seedling atrazine tolerance of indiangrass using the greenhouse soil test and conventional breeding methods is possible.
\end{abstract}

$\coprod$ NDIA NDIANGRASS is a warm-season grass native to the tallgrass prairie of North America. Establishment of indiangrass, as well as other native warm-season grasses such as big bluestem (Andropogon gerardii Vitman) and switchgrass (Panicum virgatum L.), is often difficult. Martin et al. (1982) demonstrated that the establishment of big bluestem and switchgrass could be improved if weed competition was minimized by using atrazine as a pre-emergence herbicide to control weeds. Martin et al. (1982) and Bahler et al. (1984) have documented that big bluestem and switchgrass have adequate seedling atrazine tolerance to permit the use of atrazine for weed control during establishment, while indiangrass does not. However, indiangrass had higher levels of seedling survival when exposed to atrazine than sideoats grama [Bouteloua curtipendula (Michx.) Torr.], blue grama [B. gracilis (H.B.K.) Lag. ex Steud.], and sand lovegrass [Eragrostis trichodes (Nutt.) Wood]. Some indiangrass seedlings survived atrazine applications at the rate $(2.2$ $\mathrm{kg} \mathrm{ha}^{-1}$ ) recommended for big bluestem and switchgrass establishment but not to the degree required to obtain reliable stands (Martin et al., 1982).

The mode of action of atrazine, a triazine herbicide, is the inhibition of photosynthesis; it blocks electron flow in Photosystem II (PS II) of photosynthesis (Ashton and Crafts, 1981). Many plant species possess nat-

J.G. Kube, USDA-SCS, Cape May Plant Materials Ctr., Cape May Courthouse, Cape May, NJ, NE; K.P. Vogel, USDA-ARS, Dep. of Agronomy, Univ. of Nebraska, Lincoln, NE 68583; L.E. Moser, Dep. of Agronomy, Univ. of Nebraska, Lincoln, NE 68583. Contribution of the USDA-ARS and the University of Nebraska. Published as Paper no. 8523, Journal Series, Nebraska Agric. Res. Division. Research is based on a thesis of J.G. Kube in partial fulfillment of the requirements of the M.S. degree. Received 14 Dec. 1987. *Corresponding author.

Published in Crop Sci. 29:18-23 (1989). ural tolerance or resistance mechanisms to withstand atrazine applications. LeBaron and Griessel's (1982) definition of tolerance and resistance will be used in this report. Tolerance mechanisms reduce the amount of damage that a herbicide would normally inflict, allowing the plant to develop and recover in varying degrees. Tolerance mechanisms include varying rates of uptake, translocation, and metabolism. Tolerance is usually represented by a varied response to a herbicide by individuals in a population such as a range of survivability. Resistance indicates that the herbicide does not affect the plant with its normal mode of action when it is absorbed; resistance is the maximum level of tolerance that can be achieved.

Intraspecific differences for both atrazine tolerance and resistance have been reported for both dicots and monocots (Jensen and Gressel, 1982). Intraspecific differences in herbicide tolerance can be inherited simply or quantitatively (Faulkner, 1982).

Screening for atrazine tolerance or resistance is relatively straightforward. Seedlings or plants can be grown in soil or nutrient solutions containing atrazine and mortality or other symptoms of atrazine toxicity are scored. Greenhouse trials are more effective than field trials because the atrazine treatment can be applied more uniformly and variability due to other environmental factors can also be reduced (Faulkner, 1982).

A chlorophyll fluorescence assay has been developed to screen for triazine resistance (Ahrens et al., 1981). When atrazine and similar photosynthetic inhibitors block the flow of electrons in PS II, the radiant energy that is absorbed in the initial stages of photosynthesis is dissipated as fluorescence. Relative fluorescence can be measured with a fluorometer; the greater the inhibition of photosynthesis, the greater the fluorescence. This assay was modified and evaluated by Bahler et al. (1987) on three perennial grasses (switchgrass, indiangrass, and sideoats grama) known to differ in atrazine tolerance. The fluorescence levels corresponded to the known relative differences among these grasses for seedling atrazine tolerance.

The purposes of this research were to: (i) determine the genetic variability for seedling atrazine tolerance in two previously unselected indiangrass populations by using a conventional greenhouse screen with atrazine treated soil; (ii) determine the genetic variability for atrazine tolerance of the parent indiangrass plants of the same populations using the chlorophyll fluorescence assay; (iii) determine the correlation between the two screening methods; and (iv) determine an appropriate breeding procedure for improving the seedling atrazine tolerance of indiangrass.

\section{MATERIALS AND METHODS}

Two populations of indiangrass, differing in origin, were used in this study. One population was based on Nebraska 54 (Hanson, 1972), which originated from collections in southern Nebraska. The second population was based on 
Holt, which originated from collections made in northern Nebraska (Newell and Conard, 1968). Both the Nebraska 54 (NE 54) and Holt populations used in this study had been through two cycles of restricted recurrent phenotypic selection for high yield and high in vitro dry matter digestibility (IVDMD), but had no previous selection for atrazine tolerance.

The Holt and NE 54 plants used in this study were grown in separate, isolated polycross nurseries. These were located at the University of Nebraska Agricultural Research and Development Center at Mead, NE. The soil at both nurseries was a Sharpsburg silty clay loam (fine, montmorillonitic, mesic Typic Argiudoll). The field design for both polycross nurseries was a randomized complete block with two replications. One clonal piece (ramet) of each genotype was in each replicate of the nursery. The replications in the polycross nurseries will be called field replications. The Holt polycross nursery was established in 1983 and contained 61 genotypes and the NE 54 polycross nursery was established in 1984 and contained 43 genotypes. Only 40 NE 54 genotypes and 54 (Trial 1) or 53 (Trial 2) Holt genotypes produced enough seed to be used in the study.

The polycross nursery were space planted on $1.1-\mathrm{m}$ centers. All genotypes were vegetatively propagated from their respective selection nurseries that were also at the Mead, $\mathrm{NE}$, site. Both polycross nurseries were fertilized with $45 \mathrm{~kg}$ $\mathrm{ha}^{-1} \mathrm{P}$ in April 1986, and $111 \mathrm{~kg} \mathrm{ha}^{-1} \mathrm{~N}$ in May 1985 and 1986. Weeds were controlled in both nurseries using the tandem application of Alachlor [2-chloro-2'-6'-diethyl-N(methoxymethyl) acetanilide] at the rate of $2.2 \mathrm{~kg} \mathrm{ha}^{-1}$ (AI) and 2,4-D [(2,4 dichlorophenoxy acetic acid] at the rate of $1.1 \mathrm{~kg} \mathrm{ha}^{-1}$ in April 1985 and 1986.

\section{Direct Screening for Seedling Atrazine Tolerance}

Plants in both the NE 54 and Holt indiangrass nurseries were harvested for seed on 10 and 11 Oct. 1985 , respectively. Seed was harvested, threshed, dried, and cleaned on an individual plant basis. Four sets of 100 seeds were counted out for each plant for each greenhouse trial. These seed samples were then chilled at $5^{\circ} \mathrm{C}$ for $14 \mathrm{~d}$ between blotter paper soaked with 1.55 $\mathrm{g} \mathrm{L}^{-1}$ Captan (cis-N-trichloromethyl thio-4-cyclohexene-1,2-dicarboximide) to break dormancy.

After chilling, the seeds were planted at a depth of $1.3 \mathrm{~cm}$ in greenhouse flats containing a soil-sand $\mathrm{mix}-$ ture treated with 0 or $3 \mathrm{mg} \mathrm{kg}^{-1}$ atrazine. The soilsand mixture contained $67 \%$ sand, $21 \%$ silt, $12 \%$ clay, and $0.9 \%$ organic matter, and had a pH of 5.8. Atra- zine treated soil was prepared by pipetting $18 \mathrm{~mL}$ of a $3 \mathrm{~g} \mathrm{~L}^{-1}$ atrazine/methanol solution onto $18-\mathrm{kg}$ soil lots held in brown paper bags. The methanol was allowed to evaporate overnight, and then the atrazine was thoroughly mixed into the soil by repeatedly inverting and shaking the closed bags. The soil was placed into greenhouse flats $(0.8 \mathrm{~m} \times 0.3 \mathrm{~m})$ to a depth of $7 \mathrm{~cm}$ and moistened by subirrigation before planting. All subsequent watering was also by subirrigation. Each population was tested independently in two greenhouse trials per population.

The experimental design in the greenhouse was a split-plot with two replications. The whole plot was the soil atrazine treatment ( 0 or $3 \mathrm{mg} \mathrm{kg}^{-1}$ ). Subplots were the half-sib families harvested from the individual plants in the polycross nurseries. Field replicates were a source of variation in the greenhouse study, but were not a greenhouse blocking criterion. The analyses of variance form for these trials is given in Table 1. The second Holt trial did not include the 0 mg kg-1 atrazine treatment. Two greenhouse benches (one for each replicate) contained atrazine treated flats and two other benches (except for Holt Trial 2) contained control flats with no atrazine. The benches were chosen randomly for each of the four trials and every genotype in the field nursery was represented twice (once for each field replicate) on each bench or replicate.

The 100-count seed lots of each half-sib family were planted $1 \mathrm{~cm}$ deep into labeled rows or sub-plots in the flats. Fourteen days after planting, the number of seedlings that had emerged were counted, excluding albinos. Seedling number at $14 \mathrm{~d} / 100$ was defined as the initial stand percentage. On the 26th day after planting, the number of surviving seedlings were counted. Percentage survival for each half-sib family subplot was calculated as follows:

\section{0 (number of survivors at day 26)/(Number of sur- vivors at day 14).}

The NE 54 trials were initiated on 22 April (Trial 1) and on 5 June 1986 (Trial 2). The Holt trials were initiated on 3 February (Trial 1) and on 14 Nov. 1986 (Trial 2). During the trials, greenhouse temperatures ranged from 20 to $30^{\circ} \mathrm{C}$ except for the second trial of the NE 54 progeny when temperatures rose to $40^{\circ} \mathrm{C}$ during $2 \mathrm{~d}$. Supplemental fluorescent lighting was used in the greenhouse. Daytime light readings

Table 1. Analysis of variance form and mean squares for two greenhouse screening trials for initial stands and seedling atrazine tolerance (survival percentages) in the Nebraska 54 indiangrass population.

\begin{tabular}{|c|c|c|c|c|c|c|}
\hline \multirow[b]{3}{*}{ Source } & \multirow[b]{3}{*}{ df } & \multirow[b]{3}{*}{ Expected means squarest } & \multicolumn{4}{|c|}{ Mean squares } \\
\hline & & & \multicolumn{2}{|c|}{ Trial 1} & \multicolumn{2}{|c|}{ Trial 2} \\
\hline & & & $\begin{array}{c}\text { Day } 14 \text { stand } \\
\text { percentage }\end{array}$ & $\begin{array}{c}\text { Survival } \\
\text { percentage }\end{array}$ & $\begin{array}{l}\text { Day } 14 \text { stand } \\
\text { percentage }\end{array}$ & $\begin{array}{c}\text { Survival } \\
\text { percentage }\end{array}$ \\
\hline Atrazine Rate (A) & 1 & $\sigma_{\mathrm{E}}^{2}+\mathrm{gfa} \sigma_{\mathrm{E}}^{2}+r \sigma_{\mathrm{ACF}}^{2}+\operatorname{rg} \sigma_{\mathrm{AF}}^{2}+\operatorname{rf} \sigma_{\mathrm{GA}}^{2}+\operatorname{rgf}\left(\Sigma \mathrm{Ai}^{2} / \mathrm{a}-1\right)$ & 28 & $394236^{* *}$ & 51 & $611818^{* *}$ \\
\hline Error a & 2 & $\begin{array}{c}\sigma_{\mathrm{E}}^{2}+\mathrm{gfa} \sigma_{\mathrm{E}}^{2} \\
\sigma_{\mathrm{E}}^{2}\end{array}$ & $1247^{* *}$ & $1500^{* *}$ & $1075^{* *}$ & $228^{* *}$ \\
\hline Genotype (G) & 39 & $\sigma_{\mathrm{E}}^{2}+r a \sigma_{\mathrm{GF}}^{2}+\operatorname{raf} \sigma_{\mathrm{G}}^{2}$ & $1521 * *$ & $324^{* *}$ & $1885^{*}$ & $27^{*}$ \\
\hline Field rep. (F) & 1 & $\sigma_{\mathrm{E}}^{2}+r a \sigma_{\mathrm{GF}}^{2}+\operatorname{rag} \sigma_{\mathrm{F}}^{2}$ & 87 & 77 & $407^{*}$ & 15 \\
\hline$A \times G$ & 39 & $\sigma_{\mathrm{E}}^{2}+r \sigma_{A \mathrm{AF}}^{2}+r \sigma_{\mathrm{GA}}^{2}$ & 39 & $354^{* *}$ & 48 & 34 \\
\hline$A \times F$ & 1 & $\sigma_{F}^{2}+r \sigma_{A C F}^{2}+r g \sigma_{A F}^{2}$ & 118 & 76 & 5 & 35 \\
\hline$G \times F$ & 39 & $\sigma_{\mathrm{E}}^{2}+\mathrm{ra}_{\mathrm{GF}}^{2}$ & $2700^{* * *}$ & 107 & $510^{* *}$ & 17 \\
\hline$A \times G \times F$ & 39 & $\sigma_{t}^{2}+r \sigma_{A G F}^{2}$ & 33 & 108 & 56 & 24 \\
\hline Error b & 158 & $\sigma_{\mathrm{E}}^{2}$ & 43 & 109 & 73 & 20 \\
\hline
\end{tabular}

**** Indicate significance at the 0.05 and 0.01 levels of probability, respectively.

$\dagger$ All effects were considered random except for atrazine rate. 
at bench level ranged from 65 to $590 \mu \mathrm{mol} \mathrm{m} \mathrm{m}^{-2} \mathrm{sec}^{-1}$ during the trials as measured by a Model LI-185B ${ }^{\prime}$ Quantum/Radiometer/Photometer (Li-Cor, Inc., Lincoln, NE).

Combined analyses of variance over trials were conducted for seedling survival in the $3 \mathrm{mg} \mathrm{kg}^{-1}$ atrazine treated soil for the greenhouse trials of each population, but with the 0 $\mathrm{mg} \mathrm{kg}{ }^{-1}$ treatment results excluded. The $F$-test for the equality of two variances (Snedecor and Cochran, 1967, p. 116117) was used to test for homogeneity of variances for the greenhouse trials of each population.

\section{Screening for Atrazine Tolerance using Chlorophyll Fluorescence}

The indiangrass plants in the Holt and NE 54 field nurseries were sampled and measured for relative fluorescence during July and August 1985 when plants were in late-boot to early-head developmental stages. The procedure used in taking fluorescence measurements in the field was that of Bahler et al. (1987) with minor modifications. One tiller from each field replicate was clipped and the cut end was immediately placed into a bottle of water. This maintained the turgor pressure of the tillers until fluorescence could be measured within $1 \mathrm{~h}$. Leaf disks, $7 \mathrm{~mm}$ in diam., were taken from the last fully developed leaf of each tiller, placed in separate petri dishes containing distilled water, and allowed to equilibrate for $20 \mathrm{~min}$. in full sunlight, which ranged from 1500 to $2100 \mu \mathrm{mol} \mathrm{m} \mathrm{m}^{-2}$ $\mathrm{sec}^{-1}$. Leaf disks were then removed from the distilled water and initial fluorescence readings were taken.

Fluorescence readings were taken using a Model SF20 Plant Productivity Fluorometer (Richard Branker Research Ltd., Ottawa, Canada). Fluorescence was measured with a sensing probe containing a Light Emitting Diode (LED). The LED provided light (around $670 \mathrm{~nm}$ ), stimulating photosynthesis. The resulting fluorescence ( $>710 \mathrm{~nm}$ ) was then collected by a lens in the sensing probe. Light output of the LED was measured at $10 \mu \mathrm{mol} \mathrm{m} \mathrm{m}^{-2} \mathrm{sec}^{-1}$. All fluorescence measurements were taken between 1000 and $1400 \mathrm{~h}$ with temperatures ranging from 27 to $35.5^{\circ} \mathrm{C}$.

After the initial fluorescence measurement was taken, the leaf disk was placed into another petri dish containing $10^{-3} \mathrm{M}$ atrazine/distilled water solution and a $1 \mathrm{~mL} \mathrm{~L}^{-1}$ concentration of X-77 surfactant (contains alkylarylpolyoxyethyleneglycol, fatty acids, and isopropanol) in full sunlight. After approximately $40 \mathrm{~min}$., a second fluorescence measurement was taken. the change of relative fluorescence (CRF) for each plant was calculated as:

\section{CRF $=$ Second measurement - first measurement.}

The fluorometer readout is in arbitrary units; the CRF value gives a relative number value for the effect of atrazine on each plant's photosystem. All plants in a nursery could not be measured for fluorescence in one day so a replicate-inblock experimental design was used (Comstock and Robinson, 1948) in which days were used as blocks. The genotypes in each nursery were subdivided into two sets. Both replicates of each genotype in Set 1 were measured on Day 1 and the genotypes in Set 2 were measured on Day 2. A total of

\footnotetext{
'Mention of a proprietary product, trademark, or vendor does not constitute a guarantee or warranty by the Nebraska Agricultural Research Division or the USDA and does not imply its approval to the exclusion of other products or vendors that may be suitable.
}

42 and 55 genotypes were measured for CRF for the NE 54 and Holt populations, respectively.

Heritabilities on a phenotypic mean basis averaging over replications and trials were estimated for seedling survival using the following formula from Nguyen and Sleper (1983):

$$
H=\sigma_{G}^{2} /\left[\left(\sigma_{E}^{2}+\mathrm{r} \sigma_{G T}^{2}+\mathrm{rt} \sigma_{G}^{2}\right) / r t\right]
$$

where: $\sigma_{G}^{2}=$ genetic variability among half-sib families, $\sigma_{E}^{2}$ $=$ error variance, $\sigma_{G T}^{2}=$ variance due to genotype $\times$ trial interaction effects, $r=2$ replications, $t=2$ trials.

The expected gain from selection was calculated using the following formula from Nguyen and Sleper (1983):

$$
G=\left(k c \sigma_{G}^{2}\right) / \sigma_{\mathrm{pfm}}
$$

where: $k=$ the standardized selection intensity, $c=$ the parental control factor, and $\sigma_{\text {pfm }}=$ square root of the estimated phenotypic variance among half-sib families. Variance components from the overall analyses were used to calculate the heritability estimates and the expected gains from selection. Spearman correlations were used to compare the relative ranking of genotypes between trials. Pearson correlations were used to determine the degree of relationship between the mean genotype values for CRF and seedling survival in soil treated with atrazine.

\section{RESULTS AND DISCUSSION}

\section{Direct Screening for Seedling Atrazine Tolerance}

The greenhouse screening procedure used in this study was previously shown to be predictive of the relative atrazine tolerance of grass species under field conditions by Bahler et al. (1984). The atrazine rate mean squares were not significant for Day-14 stands for either the NE 54 or Holt populations (Table 1 and 2) indicating that atrazine at $3 \mathrm{mg} \mathrm{kg}^{-1}$ concentration in the soil had no effect on the germination or emergence of indiangrass. Triazines are considered to have little if any effect on seed germination (Ashton and Crafts, 1981). Our results indicated that atrazine does not affect seed germination in indiangrass.

The first NE 54 trial was conducted in May when daily temperatures ranged from 21.5 to $28.5^{\circ} \mathrm{C}$ and light readings taken between 1000 and $1400 \mathrm{~h}$ ranged from 70 to $565 \mu \mathrm{mol} \mathrm{m} \mathrm{mec}^{-1}$ (average of $315 \mu \mathrm{mol}$ $\left.\mathrm{m}^{-2} \mathrm{sec}^{-1}\right)$. The second NE 54 trial was conducted in

Table 2. Mean squares for two greenhouse screening trials for initial stand (Trial 1 only) and seedling atrazine tolerance

\begin{tabular}{|c|c|c|c|c|c|}
\hline \multirow[b]{3}{*}{ Source } & \multicolumn{2}{|c|}{ df } & \multicolumn{3}{|c|}{ Mean Squares } \\
\hline & \multirow[b]{2}{*}{$\begin{array}{c}\text { Trial } \\
1\end{array}$} & \multirow[b]{2}{*}{$\begin{array}{c}\text { Trial } \\
2\end{array}$} & \multicolumn{2}{|c|}{ Trial 1} & \multirow{2}{*}{$\begin{array}{c}\text { Trial } 2 \\
\text { Survival } \\
\text { percentage }\end{array}$} \\
\hline & & & $\begin{array}{c}\text { Day } 14 \\
\text { stand } \\
\text { percentage }\end{array}$ & $\begin{array}{c}\text { Survival } \\
\text { percentage }\end{array}$ & \\
\hline Atrazine rate (A) & 1 & - & 128 & $432620^{* *}$ & - \\
\hline Error a & 2 & 1 & $173^{*}$ & $3250^{* *}$ & - \\
\hline Genotype (G) & 53 & 52 & $607^{* *}$ & $482^{* *}$ & $556^{* * *}$ \\
\hline Field rep. (F) & 1 & 1 & 381 & 59 & 575 \\
\hline$A \times G$ & 53 & - & $68^{*}$ & $441^{* *}$ & - \\
\hline$A \times \mathbf{F}$ & 1 & - & 55 & 1 & - \\
\hline $\mathrm{G} \times \mathrm{F}$ & 53 & 52 & $294^{* *}$ & $231^{* *}$ & 221 \\
\hline$A \times G \times F$ & 53 & - & 42 & 150 & - \\
\hline Error b & 212 & 104 & 56 & 124 & 156 \\
\hline
\end{tabular}
(survival percentages) in the Holt indiangrass population. $f$

*,** Indicate significance at the 0.05 and 0.01 levels of probability, respectively.

$\dagger$ Expected mean squares are the same as given in Table 1. 
June and July when daily temperatures ranged from 20.5 to $40^{\circ} \mathrm{C}$ and light readings ranged from 180 to $590 \mu \mathrm{mol} \mathrm{m}^{-2} \mathrm{sec}^{-1}$ (average of $460 \mu \mathrm{mol} \mathrm{m}^{-2} \mathrm{sec}^{-1}$ ). As expected, atrazine caused the greatest seedling mortality under the hot, sunny conditions in the second NE 54 trial (Table 3). The environmental conditions for the two Holt trials were more uniform, which resulted in relatively similar mortality results between the trials (Table 3 ).

The effect of atrazine rates was significant in both NE 54 trials (Table 1) for seedling survival. There were also significant differences among genotypes for seedling survival in both NE 54 trials indicating that genetic variability for seedling atrazine tolerance exists in this population (Table 1). Field replicates did not affect the seedling survival percentage. The treatment $X$ genotype interaction would be expected to be significant if there were genetic differences among indiangrass genotypes for seedling atrazine tolerance because tolerant genotypes will not react the same as nontolerant genotypes in the two different atrazine treatments. The atrazine rate $\times$ genotype interaction for seedling survival percentage was significant in Trial 1 but not in Trial 2. The high temperatures in Trial 2 probably resulted in plant stress in excess of what most genotypes could tolerate resulting in substantial seedling death even for the more tolerant genotypes.

In the Holt population there were significant differences for survival percentage between atrazine rates for Trial 1 (Table 2). The $0 \mathrm{mg} \mathrm{kg}^{-1}$ atrazine treatment was not used for the second Holt trial because the previous three trials demonstrated that atrazine did not affect germination and emergence of indiangrass. In both Holt trials, there were no significant differences detected between field replications for survival percentage. The significant genotype variability in both Holt trials and the significant atrazine rate $X$ genotype interaction in the first Holt trial indicated that genetic variability for seedling atrazine tolerance also exists in this population.

In the Holt population the genotype $\times$ field replicate (rep) interaction was significant for both Trial 1 $(P<0.01)$ and Trial $2(P<0.07)$ indicating that the effect of field replications on the seedling atrazine tolerance of progenies of clones was not the same for each genotype. This effect could have been due to field environmental effects or to nonrandom pollination in the polycross nursery. Since field rep effects were not significant, the significant field rep $\times$ genotype effects are believed to be due to nonrandom pollination. This would indicate that the genetic differences in seedling atrazine tolerance in indiangrass are transmittable via pollen and thus are probably due to nuclear genes.

Error variances were heterogeneous $(P<0.01)$ for NE 54 trials, but were homogeneous for the Holt trials. The analyses of variance over trials were combined for both populations even though the NE 54 error variances were not homogenous. The resulting $F$-test was an approximate test for the NE 54 population.

Progenies of genotypes from both populations differed significantly for seedling survival percentage in the over-trials analyses (Table 4). Some genotypes in both populations had survival percentages that were three fold that of their respective population mean (Table 3). The genotype $X$ trial effects interaction was significant for both populations. The Spearman correlation coefficients between trials for survival percentage of the half-sib families was 0.71 and 0.60 for the NE 54 and Holt populations respectively. This indicates that the significant genotype $\times$ trial effects were due more to a relative difference in response to atrazine in the separate trials than to major changes in genotype rankings in the trials. However, the magnitude of the genotypic variance $\left(\sigma_{G}^{2}\right)$ in comparison to the genotype $\times$ trial interaction variance $\left(\sigma_{G T}^{2}\right)$ indicates that duplicate trials may be necessary to consistently identify the most atrazine tolerant genotypes in a breeding program. The $\sigma_{\mathrm{G}}^{2} / \sigma_{\mathrm{GT}}^{2}$ ratios for the $\mathrm{NE}$ 54 and Holt populations were 1.2 and 3.7, respectively.

Heritability estimates for seedling survival percentage were $H=0.54$ and 0.71 for the NE 54 and Holt populations, respectively. These relatively high heritabilities indicate that it should be possible to breed for improved seedling atrazine tolerance in these two indiangrass populations using the greenhouse screening procedure based on means over two replications and two trials.

Table 4. Partial combined analysis of variance for seedling atrazine tolerance in the Nebraska 54 (NE 54) and Holt indiangrass populations.

\begin{tabular}{lccccc}
\hline & \multicolumn{2}{c}{ df } & & \multicolumn{2}{c}{$\begin{array}{c}\text { Mean square for } \\
\text { survival percentage }\end{array}$} \\
\cline { 2 - 3 } \cline { 6 - 7 } Source & NE 54 & Holt & & NE 54 & Holt \\
\hline Genotype & 39 & 52 & & $507^{* *}$ & $1146^{* *}$ \\
Genotype $\times$ Trial & 39 & 52 & & $234^{* *}$ & $329^{* *}$ \\
Error & 211 & 304 & & 121 & 220 \\
\hline
\end{tabular}

*** Indicate significance at the 0.05 and 0.01 levels of probability, respectively.

Table 3. Nebraska 54 and Holt indiangrass half-sib family means and range values for seedling survival in soil flats treated with atrazine (3 $\mathrm{mg} \mathrm{kg^{-1 }}$ ), the change of relative fluorescence values $(C R F)$ of the parent plants, and the Pearson correlation coefficients of these two estimates of atrazine tolerance.

\begin{tabular}{|c|c|c|c|c|c|c|}
\hline \multirow[b]{2}{*}{ Population } & & \multicolumn{3}{|c|}{ Seedling survival } & \multirow[b]{2}{*}{ CRF† } & \multirow{2}{*}{$\begin{array}{c}\begin{array}{c}\mathrm{CRF} \text { and seedling } \\
\text { survival correlation }\end{array} \\
r(P>0)\end{array}$} \\
\hline & & Trial 1 & Trial 2 & $\begin{array}{c}\text { Means Over } \\
\text { Trials }\end{array}$ & & \\
\hline \multicolumn{7}{|c|}{$\longrightarrow \%$} \\
\hline Nebraska 54 & $\bar{X} \pm$ SE & $\begin{aligned} 24 & \pm 5 \\
4 & -63\end{aligned}$ & $\begin{array}{l}5 \pm 2 \\
0=16\end{array}$ & $\begin{aligned} 14 & \pm 5 \\
1 & -38\end{aligned}$ & $\begin{array}{r}21.8 \pm 5.3 \\
4.5\end{array}$ & $0.13(0.41)$ \\
\hline Holt & $\begin{array}{c}\bar{X} \pm \text { SE } \\
\text { Range }\end{array}$ & $\begin{aligned} 33 & \pm 8 \\
7 & -72\end{aligned}$ & $\begin{aligned} 23 & \pm 7 \\
7 & -59\end{aligned}$ & $\begin{array}{r}28 \pm 6 \\
8-63\end{array}$ & $\begin{array}{r}23.7 \pm 9.2 \\
-3.5-50.6\end{array}$ & $0.31(0.02)$ \\
\hline
\end{tabular}

† Relative units (Bahler et al., 1984). 
Screening for Atrazine Tolerance Using Chlorophyll Fluorescence

There was significant variation among genotypes for changes in relative fluorescence (CRF) due to the atrazine treatment in both indiangrass populations (Table 5). Differences between replications for CRF values were nonsignificant indicating that repeatable readings were obtained using the fluorometer. There were considerable differences among the genotypes for CRF values as indicated by the large range of values (Table 3).

The CRF values and the over-trial mean survival percentages were not correlated for the NE $54 \mathrm{popu}$ lation and only slightly correlated $(r=0.31)$ for the Holt population (Table 3). These results indicate that mature plant atrazine tolerance as measured by CRF is not a good indicator of its progenies' seedling atrazine tolerance in indiangrass. The chlorophyll fluorescence assay can not be used on seedlings because the seedling leaves are too narrow. Thus, it is not possible to determine if mature plant and seedling CRF values are correlated. Mature indiangrass plants (1 yr or older) are tolerant of atrazine at rates up to $3.4 \mathrm{~kg}$ $\mathrm{ha}^{-1}$. The lack of correlation between mature plant CRF values and the seedling atrazine tolerance of their progeny may be due to these differences in relative atrazine tolerance among mature plants and seedlings. Ahrens et al. (1981) reported that the fluorescence assay was not an effective method of screening for known within species differences in atrazine tolerance in wheat (Triticum aestivum L.), sorghum [Sorghum bicolor (L.) Moench.] or soybean ] Glycine max (L.) Merr.] even though it was an effective assay for measuring differences in atrazine resistance among species. They also discussed the possibility that the chlorophyll fluorescence assay may not be capable of detecting intraspecific differences in atrazine tolerance if the differences in tolerance are due to mechanisms other than inhibition of PS II electron transport such as differences in metabolic rates.

\section{CONCLUSIONS}

The results of the greenhouse trials indicate that there are genetic differences among the seedling progenies of indiangrass genotypes with respect to survival in soils treated with atrazine at rates equivalent to 3.4 $\mathrm{kg} \mathrm{ha}^{-1}$. These genetic differences represent a varied

Table 5. Analysis of variance and mean squares for the change in relative fluorescence (CRF) for genotypes of the Nebraska 54 (NE 54) and Holt indiangrass populations.

\begin{tabular}{|c|c|c|c|c|c|c|}
\hline \multirow[b]{3}{*}{ Source } & \multirow{2}{*}{\multicolumn{3}{|c|}{ df }} & \multirow{3}{*}{$\begin{array}{c}\text { Expected } \\
\text { mean } \\
\text { squares }\end{array}$} & \multirow{2}{*}{\multicolumn{2}{|c|}{$\frac{\text { Mean square }}{\mathrm{CRF}^{\dagger}}$}} \\
\hline & & & & & & \\
\hline & NE 54 & Holt & Formula & & NE 54 & Holt \\
\hline Days & 1 & 1 & $(d-1)$ & & & \\
\hline Replicate/day & 2 & 2 & $d(r-1)$ & $\sigma_{\mathrm{E}}^{2}+\mathrm{g} \sigma_{\mathrm{R}}^{2}$ & 70 & 85 \\
\hline Genotype/ & & & & & & \\
\hline day $\neq$ & 40 & 53 & $d(g-1)$ & $\sigma_{\mathrm{E}}^{2}+r \sigma_{\mathrm{G}}^{2}$ & $196^{* *}$ & $428^{* *}$ \\
\hline Error & 40 & 53 & $d(g-1)(r-1)$ & $\sigma_{\mathrm{E}}^{2}$ & 56 & 169 \\
\hline
\end{tabular}

** Indicates significance at the 0.01 level of probability.

$\dagger$ Relative units.

¥ The genotypes were divided into two sets; $g$ is the number of genotypes in a set that were evaluated in a day (Comstock and Robinson 1948). response and hence are probably due to differences in tolerance rather than to differences in resistance.

Heritability estimates were relatively high indicating that substantial breeding progress could be made. A half-sib progeny test breeding procedure (Nguyen and Sleper, 1983) in which superior parents are selected on the basis of the seedling atrazine tolerance of their progeny and are intermated in isolation should result in a gain equivalent to 15 and 30 percentage units in seedling survival per cycle for the NE 54 and Holt populations, respectively, if the ten best plants were selected out of a population of 100 . The parental control factor, $\mathrm{C}$, would equal 2 in this breeding scheme (Nguyen and Sleper, 1983). We believe that this breeding procedure would be an effective method of improving seedling atrazine tolerance in indiangrass. In this study, each trial contained four replicates of each genotype because the field reps were included in the greenhouse tests. This level of replication and duplicate trials will be needed to achieve the expected gains from selection. The chlorophyll fluorescence assay does not appear to have potential as a tool for screening for seedling atrazine tolerance in an indiangrass breeding program. It would be a useful screening tool if its ability to predict seedling atrazine tolerance was higher because large populations of established plants could be screened without progeny testing. Most atrazine resistant biotypes of other species that have been evaluated to date are not as photosynthetically efficient as susceptible biotypes and hence are not as competitive in the absence of atrazine and produce less biomass (Radosevich and Holt, 1982). Atrazine resistance thus would not be as desirable as atrazine tolerance for a perennial forage grass. Breeding indiangrass for improved seedling atrazine tolerance rather than breeding for atrazine resistance should result in a product with greater economic value.

\section{REFERENCES}

Ahrens, W.H., C.J. Arntzen, and E.W. Stoller. 1981. Chlorophyll fluorescence for the determination of triazine resistance. Weed Sci. 29:316-322.

Ashton, F.M., and A.S. Crafts. 1981. Mode of action of herbicides. 2nd ed. John Wiley \& Sons, New York.

Bahler, C.C., K.P. Vogel, and L.E. Moser. 1984. Atrazine tolerance in warm-season grass seedlings. Agron. J. 76:891-895.

---, L.E. Moser, and K.P. Vogel. 1987. Using leaf fluorescence for evaluating atrazine tolerance of three perennial warm-season grasses. J. Range Manage. 40:148-157.

Comstock, R.E., and H.F. Robinson. 1948. The components of genetic variances in populations of biparental progenies and their use in estimating the average degree of dominance. Biometrics 4:254-266.

Faulkner, J.S. 1982. Breeding herbicide tolerant crop cultivars by conventional methods. p. 235-256. In Homer M. LeBaron and Johathan Gressel (ed.) Herbicide resistance in plants. John Wiley $\&$ Sons. New York.

Hanson, A. 1972. Grass varieties in the United States. USDA-ARS Agric. Handb. 170. U.S. Gov. Print. Office. Washington, DC.

Jensen, K.I.N., and J. Gressel. 1982. Table A1. Intraspecific differences in tolerance and resistance to herbicides-By herbicides. $p$. 363-374. In Homer M. LeBaron and Johathan Gressel (ed.) Herbicide resistance in plants. John Wiley \& Sons. New York.

LeBaron, H.M., and J. Gressel. 1982. Editor's notes, resistance vs. tolerance. p. 15-17. In Homer M. LeBaron and Johathan Gressel (ed.) Herbicide resistance in plants. John Wiley \& Sons. New York.

Martin, A.R., R.S. Moomaw, and K.P. Vogel. 1982. Warm-season 
grass establishment with atrazine. Agron. J. 74:916-920.

Newell, L.C., and E.C. Conard. 1968. Registration of Holt indiangrass. Crop Sci. 8:515.

Nguyen, H.T., and D.A. Sleper. 1983. Theory and applications of half-sib matings in forage grass breeding. Theor. Appl. Genet. 64:187-196.
Radosevich, S.R., and J.S. Holt. 1982. Physiological fitness of susceptible and resistant weed biotypes to triazine herbicides. p. 163183. In Homer M. LeBaron and Johathan Gressel (ed.) Herbicide resistance in plants. John Wiley \& Sons. New York.

Snedecor, G.M., and W.G. Cochran. 1967. Statistical Methods. 6th ed. The Iowa State Univ. Press, Ames, IA. 